\title{
Toward a Reading of Proverbs 3o:1b: Tracing the Life of the Text in the Versions
}

\author{
Alexander T. Kirk | ORCID: 0000-0002-9160-0030 \\ Department of Theology \& Religion, Durham University, \\ Durham, UK \\ alexander.t.kirk@durham.ac.uk
}

Published online: 18 January 2022

\begin{abstract}
Proverbs 30:1b presents one of the most intractable text-critical dilemmas in the нв. Following Ronald Troxel's suggestion that text criticism be reimagined as "a commentary on the life of the text," I suggest the way forward in reading Prov 3o:1b lies in carefully engaging with the versions as a window on its history. Emerging from this process,

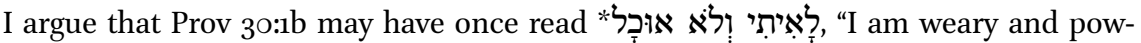
erless." Early on, however, this text was conflated with another textual tradition that read a proper name thus producing a double reading. In time, scribes harmonized this double reading which then calcified in MT. The versions and analogous biblical passages suggest the proposed text, while documented scribal practice and lexical usage support it.
\end{abstract}

\section{Keywords}

Prov 30:1 - textual criticism - the versions - Septuagint

Proverbs 30:1 contains one of the most inscrutable text-critical dilemmas in the $\mathrm{HB}$ : 


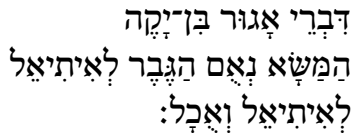

The words of Agur son of Jakeh, [man of] Massa;

The speech of the man to Ithiel,

to Ithiel and Ucal: (JPSV)

The simplest approach to the second half of the verse, illustrated by the JPSV, is to read three proper names identifying the addressees of this collection. Whether or not one adopts this reading, nearly all scholars admit the text is corrupt. ${ }^{1}$ Both the two named addressees and the awkward repetition of the first name are unusual since Proverbs, along with instructional material generally, does not identify addressees by name but rather as son(s) of the speaker/ author. $^{2}$ Moreover, although the name Ithiel is attested once (Neh 11:7), the name Ukal is unheard of. Finally, v. 2 opens with a כי clause that compounds the disorienting effect of these indecipherable characters. Most often כי כי subordinates a clause to what precedes it, suggesting to interpreters the content of the composition began in v. $1 .^{3}$ Therefore, this string of proper names leaves scholars with the distinct impression that the beginning of Agur's discourse is missing. Darkening the situation, a dearth of Hebrew manuscripts confounds text criticism of Proverbs generally and of Prov 30 in particular. ${ }^{4}$ If one turns to the ancient versions for help, their wildly divergent readings cast disorienting shadows. It is not obvious that the Septuagint $(G)$ and the Vulgate (V) are reading a Hebrew text that bears any resemblance to the Masoretic Text (MT). William McKane despairs: "Where there is hardly a glimmer of light, one feels powerless to make even the first move towards its elucidation." The text critic who hopes to untangle this knotted palindrome must do so blindfolded. Faced with such impediments, some scholars think it best

1 Sæbø, Sprüche, 359 n. 5; Toy, Proverbs, 520; Plöger, Sprüche, 358.

2 HBCE, 378.

3 Fox, Proverbs 10-31, 853.

4 The Masoretic Text is principally available in the Leningrad Codex $\left(\mathrm{M}^{\mathrm{L}}\right)$, the Aleppo Codex $\left(\mathrm{M}^{\mathrm{A}}\right)$, and the Yemenite Codex $\left(\mathrm{M}^{\mathrm{Y}}\right)$. Only fragments survived at Qumran (Prov 1:27-2:1; 13:69; 14:6-10; 14:31-15:8, 19-31); see Ulrich et al., Qumran Cave 4, 181-186. In Vetus Testamentum Hebraicum, Benjamin Kennicott compiled 200 additional Mss witnessing to MT Proverbs. This essential resource requires judicious handling because both the Mss and their presentation are of uneven reliability. For introductions to the texts and versions of Proverbs, see de Waard, Proverbs, $5^{*}-12^{*}$; HBCE, $17-19$; and the comprehensive treatment in Lange and Tov, Hebrew Bible, 241-298.

5 McKane, Proverbs, 644. 
simply to read with мт. ${ }^{6}$ Other scholars-emboldened by the desperate textual straits-propose conjectural emendations that rest on little evidence and shaky theological reconstructions. ${ }^{7}$ The majority of commentators, however, take a measured approach in redividing and repointing MT so a meaningful start to Agur's discourse emerges. ${ }^{8}$

I propose that we can illuminate this obscure verse by deepening our appreciation of the task at hand. In a recent Vetus Testamentum article, Ronald Troxel renewed the call for the collapse of higher and lower criticism. ${ }^{9}$ The task of textual criticism itself might be reconceived, not as a quest for the elusive archetype, but as "a commentary on the life of the text."10 This approach treats text criticism as an interpretive task-part of the exegetical processthat persuades to the extent it weaves a narrative explaining the evidence and yields meaningful readings. ${ }^{11}$ Similarly, Hindy Najman urges scholars to think in terms of "traditionary processes that encompass both textual formation and textual interpretation."12 Her approach would transform how we see variations within the textual tradition. Once thought of as errors and corruptions, we might now view them "as signs of life - as manifestations of the vitality of the traditions that we are studying."13 Returning to Prov 30:1b, because of the nature of the problems and the available evidence, there is little hope for a solution that will win a broad consensus. Yet contained within the versions is a

6 For example, Markus Saur reads proper names and looks for symbolic meanings; "Prophetie," 575 .

$7 \quad$ Nearly seventy years ago, Charles C. Torrey hypothesized that in order for our text to become as corrupted as it appears to be, a scribe must have intentionally moved to blot out a statement he found theologically reprehensible by translating it into Aramaic (“Proverbs," 94). Torrey's core proposal has been adopted and developed in Scott, Proverbs; Murphy, Proverbs; and now Sandoval, "Texts and Intertexts." While these approaches have produced an ingenious solution to the problem, they have done so without recourse to the textual evidence we actually possess. For example, Sandoval interacts with $\mathrm{G}$ and $\mathrm{V}$ in passing by citing their readings in footnotes, largely to claim, "the textual traditions had difficulty understanding" their Hebrew Vorlage ("Texts and Intertexts," 165; 161 n. 16; $165 \mathrm{n}$. 31). Sandoval ultimately relies on thematic parallels and theological postulations to reconstruct a hypothetical Aramaic text. My argument contends that the versions, whatever misunderstandings they may contain, constitute our only evidence and should not be dismissed so easily.

8 E.g., Delitzsch, Proverbs, 272; Clifford, Proverbs, 26o; Waltke, Proverbs, 455-456; Fox, Proverbs 10-31, 853-854; Sæbø, Sprüche, 359.

9 Troxel, "Writing Commentary."

10 Troxel, "Writing Commentary," 106. "Archetype" designates a reading for which there is no direct evidence yet whose existence explains all the others, what Ron Hendel has called the "earliest inferable textual state" ("Oxford Hebrew Bible," 329).

11 Ulrich, "Multiple Literary Editions," 114-115.

12 Najman, "Ethical Reading," 516. Emphasis original.

13 Najman, "Ethical Reading," 517. 
narrative of the struggle to understand this verse. This narrative suggests a difficult text, misunderstanding, and competing interpretive strategies and agendas. Though scholarly proposals for emending the line are legion, still lacking is an attempt to trace the life of the text through the versions, weaving a narrative that holds together all the available evidence in a compelling synthesis. ${ }^{14}$ If a path forward exists, it lies backwards through the versions.

In this paper, I examine the evidence of the versions then survey some recent text-critical approaches to Prov 30:1b. Emerging from this process, I argue that

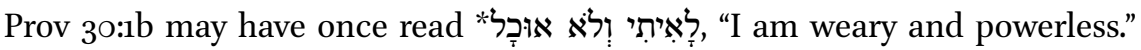
This challenging text appears to have been understood to contain a name by at least one reading tradition. This interpretation was then preserved within a MS as a double reading. Eventually, scribes harmonized this double reading which then calcified in MT. I will support this proposal by appealing to documented scribal practice concerning the preservation of doublets, the cognitive process of reading, and the creation of "ghost names" in Mss. By offering a solution as a commentary on the life of the text, not only do I hope to offer an illuminating reading of Prov 3o:1b but also to model and commend an approach to working with texts that could shed light on other dark passages.

\section{2}

\section{Narrating the Versions}

The readings of the versions do not allow us to establish an original text with any confidence but rather to explore the backstories of the text, i.e., available interpretations of our verse as it developed. ${ }^{15}$

$$
\begin{aligned}
& \text { MT: לאיתיאל לאיתיאל ואכל }
\end{aligned}
$$

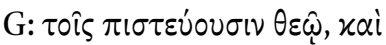

$$
\begin{aligned}
& \pi \alpha \text { v́o } \mu \alpha
\end{aligned}
$$

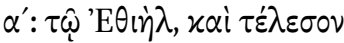

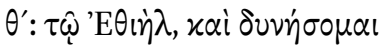

\author{
to Ithiel, to Ithiel and Ukal \\ to those believing in God, and \\ I stop \\ to Ithiel, now stop \\ to Ithiel, and I will be powerful
}

\footnotetext{
14 The most thorough treatments are by Delitzsch (Proverbs, 267-272), Fox (нвс , 378-380), and Cuppi ("Long Doublets," 88-93).

15 All translations are my own unless stated otherwise. The readings given here follow the best available critical editions for Proverbs: the Masoretic Text follows de Waard, Proverbs. Greek, i.e., the Septuagint, is given according to Rahlfs and Hanhart, Septuaginta, while Aquilla $\left(\alpha^{\prime}\right)$ and Theodotian $\left(\theta^{\prime}\right)$ are cited from Field, Origenis Hexaplorum, 37o. The Syriac (S) follows Di Lella, "Proverbs"; and the Targum (T) follow Díez Merino, Targum de Proverbios. The Vulgate is from Weber et al., Biblia Sacra.
} 


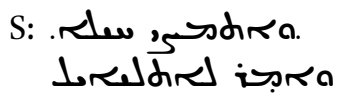

T: לאיתיאל לאיתיאל ואוכל

V: cum quo est Deus et qui Deo secum morante confortatus ait and he prevailed, and he spoke to Ithiel

to Ithiel, to Ithiel and Ukal

with whom God is, and who being strengthened by God, abiding with him, said (Douay-Rheims)

Two broad approaches to $30: 1 \mathrm{~b}$ emerge from this line up. The first approach, represented by мт, $\alpha^{\prime}, \theta^{\prime}$, T, and S, recognizes לאיתיאל as a proper name and the addressee of this composition. Within this approach only MT and T contain two occurrences of לאיתיאל and also allow for recognizing ואכל as a proper name, although nothing requires one to interpret it that way. ${ }^{16}$ Aquila, $\theta^{\prime}$, and S register only one occurrence of לאיתיאל and treat ואכל as a verb. The second approach, represented by $\mathrm{G}$ and $\mathrm{V}$, interprets all of the words understood to be proper names in other witnesses as verbal phrases. I will look more closely at the Greek versions, followed by S and V in turn, before evaluating some modern scholarly approaches to reading MT.

Nearly all the major interpretive options are already available in the Greek

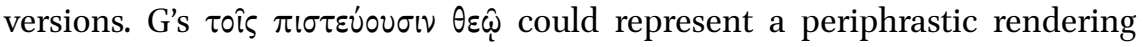
of לאיתיתי+ל ("to whom there is God"), with איתֵ construed as the Aramaic particle of existence ("there is,"

16 The Masora Parva at ואכל has the annotation ל וחס, indicating that the masoretes believed this form only occurs here written defectively. This notation suggests they asso-

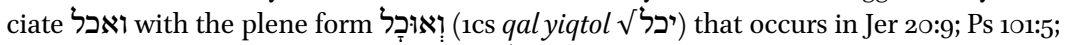
and Job 31:23 and is always qualified by לאל In other words, the masoretes appear to be reading with $\theta^{\prime}$. Kennicott records 64 out of 200 Mss with the reading ואוכל and an additional three originally contained that reading (Vetus Testamentum, 474). While this evidence cannot be used to suggest anything about the original text, it does suggest there is a strong minority tradition within мт that read ואכל as a verb.

17 At first glance, $G$ appears to have no connection to MT. However, it is possible to find correspondences between the two for all the major elements based on etymological exegesis; e.g., HBCE, 379; cf. BHQ. This is an extreme instance of the overall translation character of G Proverbs, which Fox has described as "flexible" for the sake of "control" ("A Profile," 16-17); and Forti has described as "free and even periphrastic" ("Septuagint," 254). It remains a matter of debate, however, to what extent $G$ is working from a different Vorlage (Tov, "Recensional Differences"; Cuppi, "Long Doublets," 92) or carrying out a quasi-authorial agenda (Cook, Septuagint; Waltke, Proverbs, 454 n. 1). In either case, $\mathrm{G}$ represents a different recension of the book of Proverbs. G Prov 30:1 does not give a clear indication of what the translator understood לאיתיאל to mean. On the relationship of G Proverbs to MT consider the works above; as well as Clifford, "Observations"; and Aitken and Cuppi, "Proverbs." 
e.g., Ezra 4:16; 5:17; cf. вн יש (י)..$^{18}$ This could plausibly amount to etymological exegesis of the post-exilic name איתיאל, which appears in Neh 11:7, perhaps

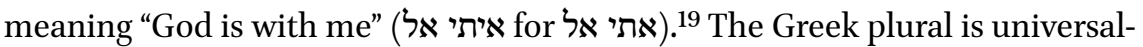
izing: "to the one whom God is with"="to anyone whom God is with." The sec-

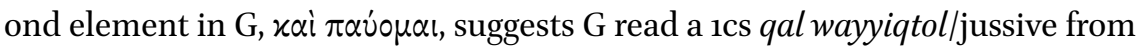
כלה

The Hexaplaric recensions, $\alpha^{\prime}$ and $\theta^{\prime}$, break from G by reflecting לאיתיאל as a proper name + ל. Aquila's reading, xai $\tau \varepsilon \dot{\lambda} \varepsilon \sigma o \nu$ ("now [you] stop"), agrees with G in finding כואכל in although it transposes the form from the first to the

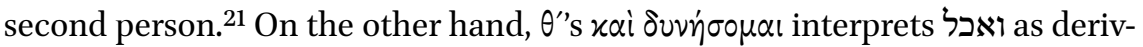
ing from $\sqrt{ } \sqrt{ }$ ("to be able, prevail"). Theodotian thus supports the vocalization represented in $\mathrm{M}^{\mathrm{L}}$ and even more so the Masora Parva and the MSs that read ואוכל ${ }^{22}$ Interestingly, both $\alpha^{\prime}$ and $\theta^{\prime}$ use the future tense. ${ }^{23}$ This strongly suggests the translators read yiqtols in their $\operatorname{Vorlage}(n)$, but it does not require a different consonantal text than MT.

Like the Greek versions, S registers just one occurrence of לאיתיאל, which it treats as a proper name. Moreover, like $\theta^{\prime}, \mathrm{S}$ treats ואכל as a verb from יכל ואכל However, $S$ differs from $\theta^{\prime}$, and from G, by apparently conflating the sense

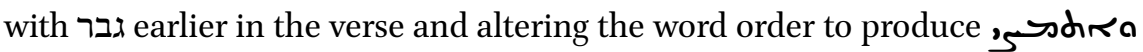
w ("and was able with strength"="prevailed"). ${ }^{24}$ We can deduce this because S has no other element synonymous with man that might correspond to גבר, and נאם is rendered verbally by The reading in S tacks most closely to $\theta^{\prime}$, the vocalization of MT, and the Kennicott MSS with ואוכל.

Although it might appear that $\mathrm{V}$ departs drastically from MT, Jerome's interpretation reflects early rabbinic exegesis. ${ }^{26}$ Consider V alongside the treatment

\footnotetext{
18 HBCE, 379 .

19 Delitzsch, Proverbs, 268; cf. Franklyn, "Sayings of Agur," 241-242 n. 14.

20 Cuppi, "Personal Names," 35; нвСE, 378.

21 This possibly echoes G's apparent אגור for v. 1a; Cuppi, "Long Doublets," 89-90 n. 25 .

22 On spelling conventions in ancient Hebrew texts and especially мт, see Barr, Variable Spellings. Barr makes the salient point that while most variable spellings were inconsequential semantically, occasionally, especially with I-` verbs, a vowel letter could distinguish one root from another (Variable Spellings, 93-94). So, while ואל יכל יכל could represent

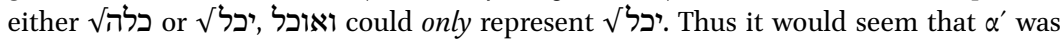

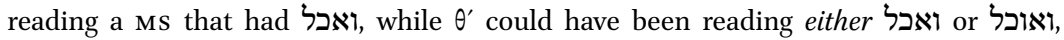
although it seems most likely his Vorlage had the plene spelling.

23 For G, Rahlfs and Hanhart, Swete, and Holmes and Parsons all record a variant with the future: $\pi \alpha \dot{\sigma} \sigma o \mu \alpha$.

24 Sokoloff and Brockelmann, A Syriac Lexicon, 815; cf. Cuppi, "Long Doublets," 90.

25 Fox, "Peshitta of Proverbs," 53.

26 Gordon, "Rabbinic Exegesis," 411.
} 
of our verse in Midrash Tanhuma, Vaera 5: "The man saith unto Ithiel is written because he [Solomon] would say: 'God is with me (iti-el), and I will be able (ukhal) to withstand temptation.' [...] The names Ithiel and Ucal were written in that verse because he said: 'I will multiply wives, but I still will not turn my heart away (Ithiel) from God; and I will multiply the number of my horses; but I will not cause the people to return."'27 This midrashic approach to the names in the verse is reflected in Jerome's translation; he may even be our earliest witness to it. ${ }^{28}$ The etymological exegesis Jerome engages in to translate the names as phrases is not far from the impulse reflected in G's reading. However, $\mathrm{G}$ registers only one occurrence of לאיתיאל while $\mathrm{V}$ exhibits two equivalent elements: 1. לאיתיאל = cum quo est Deus, 2. לאיתיאל = et qui Deo secum morante. $\mathrm{V}$ appears to witness clearly, albeit at low resolution, to мт.

\section{$3 \quad$ Evaluating Contemporary Readings}

Having thus oriented ourselves to the versions, we can now consider stories modern scholars have told about them. Jan de Waard thinks the longer text represented in $\mathrm{MT}, \mathrm{T}$, and $\mathrm{V}$ is the earlier one, based on his attribution of haplography to G and S. ${ }^{29}$ However, I find this unlikely. Why would the older witnesses-G, $\alpha^{\prime}, \theta^{\prime}$, and $S$ - all exhibit an element corresponding to only one occurrence of לאיתיאל? Surely the slavish $\alpha^{\prime}$ and $\theta^{\prime}$, which render לאיתיאל as a proper name, would have repeated that name again had it appeared twice in their respective Vorlagen. ${ }^{30}$ This observation is strengthened by the fact that $\mathrm{S}, \alpha^{\prime}$ and $\theta^{\prime}$ all read לאיתיאל as a proper name, whereas $\mathrm{G}$ reads it as a verbal phrase - the only thing they all agree on is that לאיתיאל appears once. Dittography in the tradition behind MT seems more likely than haplography behind $\mathrm{G}$ and $\mathrm{S} .{ }^{31}$ However, a more complex process is at work than a simple scribal slip.

27 Berman, Midrash, ad loc. Note Midrash Mishle employs the same strategy as Tanhuma when handling the names but arrives at a different interpretation: "to Ithiel (itiel) - [so named] because he understood the letters of God (otiyyotaw shel el); or because he understood the signs (otiyyotehen) of the ministering angels; and Ucal (ukal) - [so named] because he could (yakol) stand by them" (Visotzky, Midrash, 117; emphasis original). Both Tanhuma and Mishle derive Ukal from יכל $\sqrt{ }$, suggesting their Hebrew Mss contained ואוכל

28 Barthélemy, Proverbes, 774-775.

29 BHQ ad loc.; also Cuppi, "Personal Names," 34-35.

30 Meade, "Hexaplaric Greek Translations," 268; cf. нвсе, 38 о.

31 нвсE, 380; cf. Barthélemy, "On ne peut conclure avec certitude s'il y a eu dittographie ou haplographie"; Proverbes, 775 . 
Lorenzo Cuppi and Fox redivide and repoint the consonants of MT to arrive

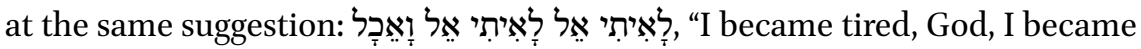
tired, God, and I may fade away."32 Dominique Barthélemy has a slightly differ-

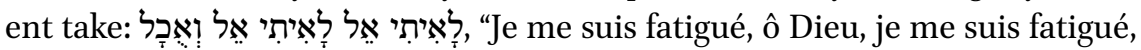

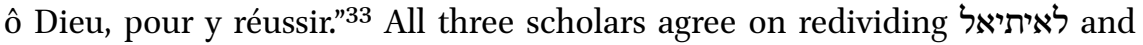
identifying it as 1cs qal qatal from לאה (to be weary, impatient) with אל לאה as a vocative. The vocative of אל tends to be signaled by the article ה, but it is possible to find exceptions (Num 12:13; Ps 83:2). More significantly, however, none of the versions or ancient MSs suggest that this vocative was ever part of the reading tradition. It appears to be the invention of modern scholars.

Where scholars differ is their handling of ואכל Following the vocalization implied by G and $\alpha^{\prime}$, Cuppi and Fox repoint ואכל ואל as a 1cs qal wayyiqtol/jussive from כלה $\sqrt{ }$. This form does not occur in the нв but is plausible (cf. Exod 39:32; Job 33:21). Fox argues כלה כלה של fits the context well since it "reverberates in the clause 'before I die' in 30:7b."34 Drawing connections to Ps 73:22 (כלה) and 2 Sam 23:1 (נאם), Fox construes Prov 30 as Agur's last words. Cuppi speculates was understood as a proper name first and this interpretation eventually contributed to ואכל being taken the same way. ${ }^{35}$ But why this text was misread in the first place remains a question. Cuppi tentatively suggests that without vowels an Aramaic speaker might have scanned the consonantal text

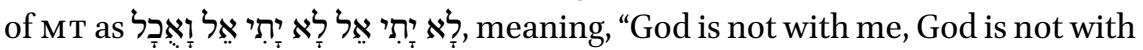
me, and I will succeed." ${ }^{36}$ The translations of $G$ and $V$, along with the Midrash Tanhuma, support the plausibility of this. Barthélemy, however, opts to retain M T's pointing of ואכל as a 1cs qal yiqtol from יכל ה indirectly by V. Moreover, Barthélemy's suggestion has the strength that it does not require altering M T at all and is even supported by the Kennicott Mss reading ואוכל evidence-is his observation that לאה is followed by יכה in Isa 16:12; Jer 20:9; and Job 4:2. No verse, however, brings together לאה and כלה בל יכל Ind

\footnotetext{
32 Cuppi, "Personal Names," 35; нвсе, 378.

33 Barthélemy, Proverbes, 775.

34 HвCE, 378.

35 Cuppi, "Long Doublets," 91.

36 Cuppi, "Long Doublets," 91-92.

37 See $n .17$ and 23 above.
} 
Taking all this evidence and scholarly ingenuity under advice, what can we say with any confidence? Lines of correspondence connect elements of $G, \mathrm{~V}$, and MT despite the meaning being changed systematically. This indicates the periphrastic interpretation in $\mathrm{G}$ and $\mathrm{V}$ is intentional and exegetical. The midrashic tradition latched on to these words. Because interpretive traditions are in play, and G's translation style is flexible overall, retroversion is challenging. Still, first and foremost, it is probable that only one instance of לאיתיאל is original and ואכל began life as a verb. This is the majority opinion of the ancient versions, including all of the oldest witnesses. I cannot see how ואכל could have originated either as a second addressee or hanging off the end of the title line as a lonely verb, stranded from the body of the poetic composition as in G. If לאיתיאל probably represented a verbal phrase as well. We already have two early interpretations represented in Greek. G takes as a verbal phrase ("to those believing in God") while $\alpha^{\prime}$ and $\theta^{\prime}$ take it as a proper name ("to Ithiel"). But these traditions both interpret this phrase as indicating the addressee through the use of the preposition ל. Perhaps this was the inciting incident. If לאיתיאל originally contained a verbal phrase, then it is easy to imagine how a on a strange lexeme in the superscript of a discrete collection could have triggered a scribe to think in terms of an addressee. Perhaps eventually both the verbal phrase and the tradition representing an addressee were included in one manuscript by a scribe who did not know which was the correct reading. This scribe may have inserted a double reading that differed by as little as a word division or the transposition of two letters. Over time, MT's baffling reading calcified as the distinctions between these two interpretive options were lost.

But how might this have occurred and what could the original text have been? Building on Barthélemy's approach, I will suggest a reading for Prov 30:1b that produces a plausible history of the transformation of the text grounded in both the evidence of the versions and emerging text-critical methodology.

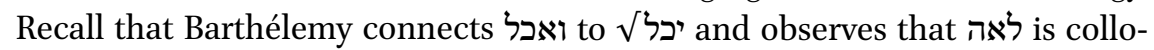
cated with יכל in Isa 16:12; Jer 20:9; Job 4:2. The verb יכל יכל occurs just thirty-four times in the qal. Twenty-seven of these are negated. Two of the three examples where יכל is followed by into this category:

Jer 20:9

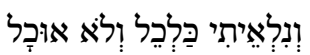

I am weary from containing [it] and I am no longer able. 
Isa 16:12

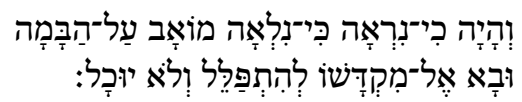

So it will be when he appears that Moab has wearied himself on the high place, and he will enter his sanctuary to pray but he will not be able.

Might Prov 30:1 be reflecting this collocation of לאה + negator + יכל that we find in Jer 20:9 and Isa 16:12? Perhaps in place of אל text had the adverb לא negating the verb? ${ }^{38}$ The proposed earlier text would then have been:

\section{1. לאיתי ולא א(ו)כל}

I am weary and not able (i.e., powerless).

Apart from the optional i, this phrase contains identical consonants to MT, differing only in word division and the transposition of letters. ${ }^{39}$ In contrast to other text-critical solutions, a compelling case can be made that such a primary text produced the readings in the versions.

First, note that לאה is a relatively rare verb with just nineteen occurrences and of those only three are in the qal. This form would be unique in the нв although it is quite plausible. Second, remember that אכל potentially derives from several different roots when written defectively. Third, consider the density of lameds (3x), alephs (3x), and yods and waws (3x) in the proposed text. These four graphemes account for nine out of eleven letters. Considering the semantic and graphic difficulty in this clause, there are many things that could go wrong in transcription. All it would take to trigger a process of transformation is one of several common scribal errors. This is the first stage in the process. By simply misdividing the words and running them together the scribe may have produced *לאיתיולא. Graphic confusion between ו and ' would

38 In 1891, Gustav Bickell proposed something similar: אכל [לא]לאתי אל ו / לאתו (Kritische Bearbeitung, 293). He translates, "Ausspruch des Mannes, der sich um Gott abgemüht hat: ich habe mich um Gott abgemüht und es nicht vermocht." Unfortunately, Bickell's project concerns justifying a theory of prosody and he provides little explanation for his proposal, but he anticipated two important aspects of mine. He discerned that the repetitions of לאיתיאל originally preserved different readings and that אכל was likely negated.

39 I represent the 1 in in parentheses to indicate it may or may not have been present in different MSs and stages of the transmission process. If one considers plene and defective spellings, various orthographic options emerge. My argument is not married to one spelling, but is aided by the fact that orthography was not standardized in ancient texts. See Barr, Variable Spelling, 7-11. 
yield לאיתי ילא* or לאיתו ולאיא. These readings are primed for elision, producing * לאיתולא* or לאיתילא. Likewise, the back-to-back ss could easily have been elided. Finally, metathesis of the לאיתי ואל* ל לא one of these shifts occurred a second would be even more likely if only to make sense of the first. For example, the elision of an could have produced וכל Searching for a meaning for scribe may have vocalized it as the

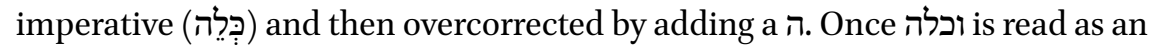
imperative there is no meaningful role for $\boldsymbol{k}$, which could have been absorbed into לאיתיאל וכלה * to reliable retroversion of $\alpha$ ' is born. It is easier to arrive at a retroversion of $\theta$ '. The letters of ולאלה לאל ולאל 'simply have to be reversed

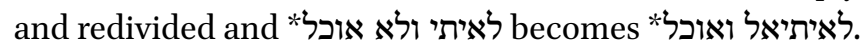

In my opinion, such errors need not represent stages in manuscript transmission. Rather, they probably occurred as simultaneous elements of the translator-scribe's natural mental process of reading. As John Screnock argues in Traductor Scriptor, scribes and translators both construct mental versions of texts based on but not identical to the physical Vorlagen in front of them. ${ }^{40}$ By using resources from translation studies, particularly intralingual translation, Screnock argues that translation and transmission of Mss involve fundamentally similar cognitive processes. ${ }^{41} \mathrm{He}$ explains, "the translation process does not involve one single move from the physical Vorlage directly to the physical text of the translation; rather, there are additional intermediary stages in the translator's mind, appropriately conceived of as texts, through which this move is channeled."42 Through a process of working memory and phonological loops, the translator-scribes produce physical copies of their Vorlage from their mental text. ${ }^{43}$ One of the implications of Screnock's study is that many variants in the textual tradition stem from the decoding (i.e., reading) process within the translator's mind rather than errors of the eye and ear or the Vorlagen. ${ }^{44}$ To recall Emanuel Tov's dictum, many reliable variants never actually existed in writing. ${ }^{45}$

I propose that a reading glitch triggered a scribe to decode לאיתי ולא as a proper name. While it is possible one of the classic errors of textual criticism was at work (e.g., dittography, haplography, or metathesis as described above), it is equally likely that the scribe simply misread a difficult string of letters

\footnotetext{
40 Screnock, Traductor Scriptor, 178-179.

41 Screnock, Traductor Scriptor, 92.

42 Screnock, Traductor Scriptor, 177.

43 Screnock, Traductor Scriptor, 86-88.

44 Screnock, Traductor Scriptor, 35 and 179.

45 Tov, Text-Critical Use, 178. Tov's original wording is, "One simply has to accept the fact that some reliable retroversions never existed in writing."
} 
in a fraught context. For example, in the Antiochene recension of G, Natalio Fernández Marcos has identified a phenomenon he dubbed "ghost names." Ghost names appear when a challenging string of letters in a Hebrew Vorlage is interpreted as a proper name and then translated as such. ${ }^{47}$ This device creates a meaning in the target language that did not exist in Hebrew. ${ }^{48}$ For example, in 1 Kgs 15:22 the Hebrew phrase אין נקי ("without exception") emerges in the

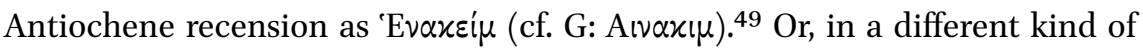
example, 1 Sam 14:33 has the verb בְגְרדת ("you acted treacherously") represented in the $\mathrm{G}$ as a place name $\Gamma \varepsilon \theta \theta \varepsilon \mu$. The Antiochene recension, however, represents it as a place name twice; once as in $\mathrm{G}$ and again as $\mathrm{H} \mu \alpha \dot{p} \tau \varepsilon \tau \varepsilon-$ still a proper name but translated "ad sensum with recourse to the verb $\dot{\alpha} \mu \alpha \rho \tau \dot{\alpha} \varepsilon \varepsilon v . " 50$ Fernández Marcos emphasizes the vast majority of ghost names are "attested in sequences of double readings,"51 and "occur especially in the genealogical material at the start of 1 Chronicles where the absence of a meaningful context cause [sic] major confusion of similar letters in Hebrew and throughout the Greek tradition."52 He cautions scholars to attend to proper names because they often convey semantic information: "[...] they have been incorporated by the scribes to the narrative, circulated for centuries as part of the official biblical text for a community, and gave rise to new meanings, exegesis and commentaries. And in a few cases they preserve very ancient, alternative variants that may go back to a Hebrew text different from the Masoretic one."53

The phenomena analyzed by Screnock and Fernández Marcos help explain the process I believe took place in the transmission of Prov 30:1b. While transcribing the superscript of a new collection within Proverbs, a scribe sees a followed by a string of letters (לאיתי). In context, he processes this relatively rare set of letters as the name Ithiel (Neh 11:7). Once *ליתי ולאי ל לאי was transcribed into a physical Ms as a name, the traditions diverge - the earlier verbal phrase

46 The term "ghost names" is derived on analogy with the phenomenon of "ghost words" famous in classical philology from Greek lexicography. Ghost words are "created in the minds of the editors of texts (especially papyri and inscriptions) as a set of conjectures which eventually, in the light of new studies or new witnesses, have proved to be false readings" (Fernández Marcos, "On the Borderline," 14). The lexicons typically record these words in brackets.

47 Fernández Marcos, “On Double Readings," 598.

48 Fernández Marcos, "On the Borderline," 20.

49 Fernández Marcos, “On the Borderline," 16.

$50 \quad$ Fernández Marcos, "On the Borderline," 16.

$5^{1} \quad$ Fernández Marcos, "On the Borderline," 19.

52 Fernández Marcos, "On Double Readings," 6 oo.

53 Fernández Marcos, “On the Borderline," 21. 
was preserved in one tradition and the newly fashioned addressee in another. At stage two the novel text may have read:

\section{2. לאיתיאל א(ו)כל}

To Ithiel: I am able.

At this point - if they had not already done so - the traditions represented by the Greek and Syriac versions diverge from мт. Orthography - the optional $ו$ in 1 -could have been the factor differentiating $\alpha^{\prime}$ and $\theta^{\prime \prime}$ s readings. In my opinion, $G$ probably also witnesses to example 2, although it interpreted the name by translating its constitutive elements. ${ }^{54}$ A conjunction on אכל may have been inserted at any stage in the process after לאיתיאל was interpreted as a proper name in order to make sense of the verb and smooth out the reading. Alternatively, if אוכל was in the Vorlage, the scribe could have engaged in exegetical metathesis of the 1 and the $\aleph$, whether intentionally or unintentionally, in order to make sense of his text. ${ }^{55}$

Years pass. Faced with alternative readings in competing Vorlagen, a scribe is unable to adjudicate between them and represents both side by side in a fresh Ms, presenting them as complementary options for the interpreter. ${ }^{56}$ This is stage three and the text may have looked like this:

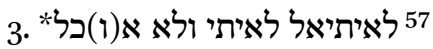

To Ithiel, I am weary and powerless.

Despite the lack of direct evidence for this stage, a double reading seems the most plausible explanation for how לאיתיאל came to be duplicated in мт. ${ }^{58}$

54 Fernández Marcos, "On Double Readings," 592. There is no way to rule out the possibility that $\mathrm{G}$ is working from a Hebrew Vorlage similar to example 1 . In which case, $\mathrm{G}$ represents a rendering of the translator's mental text.

55 de Waard, "Metathesis."

$5^{6}$ Shemaryahu Talmon details the process whereby this happened relatively frequently in many different Mss. He emphasizes that identifying instances where doublets entered the text is devilishly hard; "Double Readings."

57 There would have been a consonantal difference between the two options at this point in order for the scribe to preserve them as variables.

$5^{8}$ Indirectly supporting this conclusion, both Otto Plöger and Bruce Waltke prefer emendations that handle the occurrences of לאיתיאל differently. Building on Bickell's proposal,

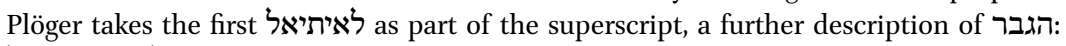
לֶֶה אֵת־ָָאל ,Der sich um Gott abmühte." This third-person description is immediately echoed in the first-person in the opening of Agur's discourse: לָאִיתִי אָל (Sprüche, 353-354, 358). I believe Plöger is correct in offering two readings that are similar consonantally but 
First, the versions testify that there was a time before the double reading entered the ms tradition. Second, לאיתיאל has not always been a name but has sometimes been understood as a verbal phrase, and the midrashic approach of $\mathrm{G}$ and $\mathrm{V}$ suggests it was originally a verbal phrase different from those that have been preserved. Third, the phenomenon of incorporating alternative textual traditions into one MS as a double reading is a known practice whereby texts grew and preserved "alternative wordings of the same texts." 59

In the fourth and final stage of transmission, the traditions preserved in the double reading — still graphically and semantically challenging - were harmonized toward one another. This could have been accomplished through a similar set of scribal errors described above or through a simpler process of homeoarchy resulting in dittography of לאיתיאל triggered by the reduplication of no less than five consonants in the postulated Vorlage (לאיתי). Once both readings were harmonized as this double addressee, we arrive at the text of MT and at $\mathrm{T}$ and $\mathrm{V}$, which witness to it. The move to interpret ואכל as a name only comes at this stage. Strictly speaking, "Ukal" is not part of the textual tradition, since MT can still be read as a verb, especially if one adopts the minority reading of the Kennicott Mss. The same is true of T (cf. Dan 2:10; 5:16). Only V, in reflecting the midrashic tradition, demands to be read as a name.

If my proposal is compelling, Agur's כי clause in v. 2 now depends on a line that confesses his weakness and ineptitude in a striking manner. Both יכל ane clear uses where the emphasis is on an acute mental weariness and emotional exasperation over sin (Exod 7:18; Isa 1:14; 7:13; 47:13). In Job 4:2 and 5, Eliphaz uses לאה twice to describe Job as edgy, impatient, easily offended. Similarly, in certain distinctive phrases יכה למי means "to endure" within the spiritual/psychological realm (Ps 101:5; Job 31:23). In Ps 139:6, לאל + יכל " describes the psalmist's inability to attain to the knowledge of God. Notably, when יכל are used in close quarters they focus on spiritual exasperation. In Isa 1:13-14, YHWH denounces Israel, saying he cannot endure (לאל-אוכל) their iniquity and assemblies; and he grows weary of bearing (נלאיתי נשאה) their feasts (cf. Jer 20:9 above). Agur's combination of these two lexemes in a context where he is confessing his intellectual limits suggests his weariness is not necessarily physical but acutely psychological and even spiritual. Agur opens on a note of profound exasperation..$^{60}$

distinct semantically. Similarly, Waltke deduces the purpose for which I believe the doublet was originally preserved by transliterating the first instance as "Ithiel" and translating the second instance, "I am weary, O God" (לָאִִיתִי אִל) (Proverbs, 455).

59 Talmon, "Double Readings," 15 o.

6o Sæbø, Sprüche, 363 . 
Proverbs 30:1b was always a challenging string of letters and it has been understood and interpreted in various ways throughout its history. Early on, at least one scribe expected an addressee and read a proper name. The resulting texts, one with a proper name and one without, were eventually conflated producing a double reading. Midrashic traditions came into play to explain the text. In time, various readings calcified. If I were editing a critical edition of Prov 30, I would probably offer a retroversion of $\theta^{\prime}$ as the "the earliest recoverable Hebrew text" of v. 1b, e.g., "לאיתיאל ואוכל. But I remain convinced this "earliest recoverable Hebrew text" is not the "earliest inferable textual state." ${ }^{11}$ I believe the text of Prov 30:1b could have once read *לאיתי ולא אוכל, "I am weary and powerless." But this reconstruction still necessitates interpretation. I have argued for reading ואכל as 1cs qal yiqtol from יכל

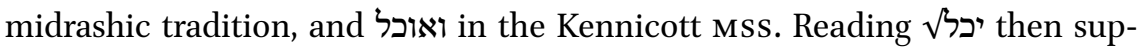
ports the contextual reading of לאיתיאל on analogy with the collocation of יכל + in Isa 16:12 and Jer 20:9. As an opening to Agur's discourse, "I am weary and powerless" offers intriguing possibilities by connecting to Agur's core themes of human finitude and the location of wisdom.

The approach modeled here is what I take Troxel's collapse of higher and lower criticism to entail. Tracing the life of a text back through the versions can suggest a reading that might plausibly lie behind all of them, particularly where we lack sufficient Mss evidence to compare, count, and weigh readings. Counter-intuitively, the more cautious approach of redividing and repointing MT probably creates a text that never actually existed in the history of transmission. It is true, as Moshe Goshen-Gottstein has said, that "there is no retroversion without a residue of doubt." ${ }^{\prime 2}$ However, it is equally true that every reading in the versions contains a fragment of the history of wrestling with and transforming the text. As text critics we are interpreters who concern ourselves with that history. We bring the most light to bear on the text and offer the richest interpretations when we judiciously engage all the evidence the textual traditions have preserved..$^{63}$

\footnotetext{
$61 \quad$ Troxel, "Writing Commentary," 128; cf. ibid., 106 n. 6.

62 Goshen-Gottstein, "Theory and Practice," 132.

63 Goshen-Gottstein argues that we would do well to identify doublets and preserve both readings in the apparatus of our critical editions because, on principle, we cannot know which readings preserve true variants and which readings do not. Recently, Screnock ("A New Approach") has proposed updating Tov's methodology for retroverting the Septuagint in order to admit more data into the text-critical process.
} 


\section{Acknowledgement}

Many thanks to Stuart Weeks and John Screnock, who both carefully read multiple drafts of this paper and made dozens of helpful suggestions that strengthened the argument and saved me from error. Joseph Justiss read a late draft and pressed many astute questions. My thanks are also due to the peer reviewers and editors at Vetus Testamentum whose keen eyes made many corrections. All opinions, especially errors, remain mine alone.

\section{Bibliography}

Aitken, James K., and Lorenzo Cuppi. "Proverbs." Pages $341-355$ in The T\&T Clark Companion to the Septuagint. London: Bloomsbury, 2015.

Barr, James. The Variable Spellings of the Hebrew Bible. Oxford: Oxford University Press, 1989 .

Barthélemy, Dominique. Job, Proverbes, Qohélet Et Cantique Des Cantiques. Vol. 5 of Critique Textuelle De L'Ancien Testament. ово 5о. Göttingen: Vandenhoeck \& Ruprecht, 2015 .

Berman, Samuel A. Midrash Tanhuma-Yelammedenu: An English Translation of Genesis and Exodus from the Printed Version of Tanhuma-Yelammedenu with an Introduction, Notes, and Indexes. Hoboken, NJ: KTAV, 1996.

Bickell, G. "Kritische Bearbeitung der Proverbien: Mit einem Anhange über die Strophik des Ecclesiasticus." Vienna Oriental Journal 5 (1891): 271-299.

Clifford, Richard J. "Observations on the Text and Versions of Proverbs." Pages 47-61 in Wisdom, You Are My Sister: Studies in Honor of Roland E. Murphy, O. Carm., on the Occasion of His Eightieth Birthday. Edited by Michael L. Barré. свQмS 29. Washington, D.C.: Catholic Biblical Association, 1997.

Clifford, Richard J. Proverbs: A Commentary. OTL. Louisville: Westminster John Knox, 1999 .

Cook, Johann. The Septuagint of Proverbs: Jewish and/or Hellenistic Proverbs? Concerning the Hellenistic Colouring of LXX Proverbs. VTSup 69. Leiden: Brill, 1997.

Cuppi, Lorenzo. "Long Doublets in the Septuagint of the Book of Proverbs with a History of the Research on the Greek Translations." PhD diss., Durham University, 2011.

Cuppi, Lorenzo. "The Treatment of Personal Names in the Book of Proverbs from the Septuagint to the Masoretic Text." Pages 19-39 in Greek Scripture and the Rabbis. Edited by T. M. Law and Alison Salvison. Свет 66. Leuven: Peeters, 2012.

Delitzsch, Franz. Biblical Commentary on the Proverbs of Solomon. Translated by M. G. Easton. Clark's Foreign Theological Library 47. Edinburgh: T\&T Clark, 1875. 
Di Lella, Alexander A., John Adney Emerton, and D. J. Lane, eds. Proverbs, Wisdom of Solomon, Ecclesiastes, Song of Songs. Vol. 2, part 5 of The Old Testament in Syriac, According to the Peshitta Version. Edited by Peshitta Institute Leiden. Leiden: Brill, 1979 .

Díez Merino, Luis. Targum De Proverbios: Edición Príncipe Del Ms. Villa-Amil No. 5 De Alfonso De Zamora. Bibliotheca Hispaña Biblica 11. Madrid: Consejo Superior de Investigaciones Científicas, 1984.

Fernández Marcos, Natalio. "On the Borderline of Translation Greek Lexicography: The Proper Names." JNSL 27.2 (2001): 1-22.

Fernández Marcos, Natalio. "On Double Readings, Pseudo-Variants and Ghost-Names in the Historical Books." Pages 591-6o4 in Emanuel: Studies in the Hebrew Bible, Septuagint, and Dead Sea Scrolls in Honor of Emanuel Tov. Edited by Shalom M. Paul, Robert A. Kraft, Lawrence H. Schiffman, and Weston W. Fields. VTSup 94. Leiden: Brill, 2003.

Field, Frederick. Origenis Hexaplorum Quae Supersunt. Oxford: Clarendon, 1875.

Forti, Tova. "Septuagint." Pages 253-259 in The Hebrew Bible: Writings. Edited by Armin Lange and Emanuel Tov. Vol. $1 \mathrm{C}$ of Textual History of the Bible. Edited by Armin Lange. Leiden: Brill, 2017.

Fox, Michael V. Proverbs 10-31: A New Translation with Introduction and Commentary. AB 18B. New Haven: Yale University Press, 2009.

Fox, Michael V. "How the Peshitta of Proverbs Uses the Septuagint." JNSL 39.2 (2013): 37-59.

Fox, Michael V. "A Profile of the Septuagint Proverbs." Pages 3-17 in Wisdom for Life: Essays in Honor of Maurice Gilbert. BZAW 445. Berlin: de Gruyter, 2014.

Fox, Michael V. Proverbs: An Eclectic Edition with Introduction and Textual Commentary. The Hebrew Bible, a Critical Edition 1. Atlanta: SBL, 2015 [= HBCE].

Franklyn, Paul. “The Sayings of Agur in Proverbs 30: Piety or Scepticism?” ZAW 95 (1983): 238-252.

Gordon, Cyrus H. "Rabbinic Exegesis in the Vulgate of Proverbs." JBL 49 (1930): 384-416.

Goshen-Gottstein, Moshe H. "Theory and Practice of Textual Criticism:TheText-Critical Use of the Septuagint." Text 3 (1963) : 130-158.

нвсE, see Fox.

Hendel, Ronald. "The Oxford Hebrew Bible: Prologue to a New Critical Edition." vT 58 (2008): 324-351.

Holmes, R., and J. Parsons. Vetus Testamentum Graecum Cum Variis Lectionibus. Oxford: Clarendon, 1823 .

Kennicott, Benjamin. Vetus Testamentum Hebraicum Com Variis Lectionibus. Oxford: Clarendon, 178 o.

Lange, Armin, and Emanuel Tov, eds. The Hebrew Bible: Writings. Vol. $1 \mathrm{C}$ of Textual History of the Bible. Edited by Armin Lange. Leiden: Brill, 2017. 
McKane, William. Proverbs: A New Approach. otL. Philadelphia: Westminster, 1970.

Meade, John. "Hexaplaric Greek Translations." Pages 267-270 in The Hebrew Bible:

Writings. Edited by Armin Lange and Emanuel Tov. Vol. $1 \mathrm{C}$ of Textual History of the Bible. Edited by Armin Lange. Leiden: Brill, 2017.

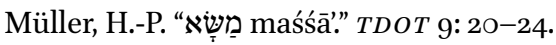

Murphy, Roland E. Proverbs. WBC 22. Nashville: Thomas Nelson, 1998.

Najman, Hindy. "Ethical Reading: The Transformation of the Text and the Self." JTs 68 (2017): 507-529.

Plöger, Otto. Sprüche Salomos (Proverbia). BKAT 17. Neukirchen-Vluyn: Neukirchener Verlag, 1984.

Rahlfs, Alfred, and Robert Hanhart. Septuaginta. Stuttgart: Deutsche Bibelgesellschaft, 2006.

Sæbø, Magne. Sprüche. AT D 16,1. Göttingen: Vandenhoeck \& Ruprecht, 2012.

Sandoval, Timothy J. "Text and Intertexts: A Proposal for Understanding Proverbs 30.1b." JSOT 45 (2020): $15^{8-177 .}$

Saur, Markus. "Prophetie, Weisheit und Gebet: Überlegungen zu den Worten Agurs in Prov 30,1-9." ZAW 126 (2014): 570-583.

Scott, R. B. Y. Proverbs, Ecclesiastes. AB 18. Garden City, NY: Doubleday, 1965.

Screnock, John. Traductor Scriptor: The Old Greek Translation of Exodus 1-14 as Scribal Activity. VTSup 174. Leiden: Brill, 2017.

Screnock, John. "A New Approach to Using the Old Greek in Hebrew Bible Textual Criticism." Text 27 (2018): 229-257.

Sokoloff, Michael, and Carl Brockelmann. A Syriac Lexicon: A Translation from the Latin, Correction, Expansion, and Update of C. Brockelmann's Lexicon Syriacum. Winona Lake, IN: Eisenbrauns, 20o9.

Swete, Henry Barclay. The Old Testament in Greek According to the Septuagint. Cambridge: Cambridge University Press, 1891.

Talmon, Shemaryahu. "Double Readings in the Masoretic Text." Text 1 (1960): 144-184. Torrey, Charles C. "Proverbs, Chapter 30." JBL 73 (1954): 93-96.

Tov, Emanuel. "Recensional Differences Between the Masoretic Text and the Septuagint of Proverbs." Pages 43-56 in Of Scribes and Scrolls: Studies on the Hebrew Bible, Intertestamental Judaism, and Christian Origins, Presented to John Strugnell on the Occasion of His Sixtieth Birthday. Edited by John Strugnell et al. Lanham, MD: University Press of America, 199 o.

Tov, Emanuel. The Text-Critical Use of the Septuagint in Biblical Research. 3rd rev. and exp. ed. Winona Lake, IN: Eisenbrauns, 2015.

Toy, Crawford H. A Critical and Exegetical Commentary on the Book of Proverbs. ICC. Edinburgh: T\&T Clark, 1899.

Troxel, Ronald L. “Writing Commentary on the Life of a Text." vT 67 (2017): 105-128. 
Ulrich, Eugene. "Multiple Literary Editions: Reflections Toward a Theory of the History of the Biblical Text." Pages 99-120 in The Dead Sea Scrolls and the Origins of the Bible. Grand Rapids: Eerdmans, 1999.

Ulrich, Eugene et al. Qumran Cave 4:XI, Psalms to Chronicles. DJD 16. Oxford:Clarendon, 2000 .

Visotzky, Burton L. The Midrash on Proverbs. YJs. New Haven, CT: Yale University Press, 1992.

Waard, Jan de. "Metathesis as a Translation Technique?" Pages 249-26o in Traducere Navem: Festschrift Für Katharina Reiss zum 70. Geburtstag. Edited by Justa Holz-Mänttäri and Christiane Nord. Tampere: University of Tampere, 1993.

Waard, Jan de. Proverbs. BHQ 17. Stuttgart: Deutsche Bibelgesellschaft, 2008.

Waltke, Bruce K. The Book of Proverbs: Chapters 15-31. NICOT. Grand Rapids: Eerdmans, 2005 .

Weber, Robert et al. Biblia Sacra: Iuxta Vulgatam Versionem. Stuttgart: Deutsche Bibelgesellschaft, 1994 . 